\title{
44. THE INFLUENCE OF BIOGENIC SILICA ON SEISMIC LITHOSTRATIGRAPHY AT ODP SITES 642 AND 643, EASTERN NORWEGIAN SEA ${ }^{1}$
}

\author{
Peter Hempel, ${ }^{2}$ Larry Mayer, ${ }^{3}$ Elliott Taylor, ${ }^{4,5}$ Gerhard Bohrmann, ${ }^{6}$ and Alan Pittenger ${ }^{7}$
}

\begin{abstract}
Drilling at ODP Sites 642 and 643 revealed a 250 m-thick section of diatomaceous Pliocene to Miocene sediments on the outer Vøring Plateau, eastern Norwegian Sea. These biogenic silica-rich sediments have a significantly lower saturated bulk density than the surrounding sediments, causing a decrease in acoustic impedance, which is seismically expressed as a negative polarity reflection. Variations in sonic velocity, the other key parameter in seismic analysis, is only of secondary importance in creating impedance contrasts in our study. Synthetic seismograms were produced from shipboard physical property measurements corrected for in situ conditions. These synthetic seismograms are in good agreement $(\leq 6 \mathrm{~m})$ with high-resolution air-gun seismic profiles shot during extensive seismic surveys on the Vøring Plateau and provide the basis for correlations between the seismic record and the borehole. The ability to unambiguously identify seismic horizons associated with biogenic silica deposits on the Vøring Plateau will permit the mapping of Miocene productivity patterns.
\end{abstract}

\section{INTRODUCTION}

The Vøring Plateau, situated in the eastern Norwegian-Greenland Sea (Fig. 1), has been the target area of two deep-sea drilling expeditions, Leg 38 of the Deep Sea Drilling Project (DSDP) (Talwani, Udintsev et al., 1976) and Leg 104 of the Ocean Drilling Program (ODP) (Eldholm, Thiede, Taylor, et al., 1987) and of numerous seismic surveys. The first regional investigation of Tertiary and Mesozoic sediment distribution in the NorwegianGreenland Sea was carried out by Eldholm and Windisch (1974). Sellevoll (1975) mapped the sediment distribution east of the Vøring Plateau Escarpment. Among others Hinz et al. (1984) and Mutter (1984) investigated the evolutionary history of the passive continental margin at the Vøring Plateau.

The drilling results of ODP Leg 104, on which this study concentrates, provide a continuously cored and relatively undisturbed sequence of Eocene flow basalts to Quaternary glacial/ interglacial deposits, with an average core recovery of $88.74 \%$ at Site 642 and $86.67 \%$ at Site 643 for the sedimentary section. Nearly all Miocene sediments (ca. $250 \mathrm{~m}$ thick) recovered at ODP Sites 642 and 643 are characterized by a high abundance of well-preserved biogenic silica, comprised predominantly of diatom frustules. The significant differences between the physical properties of the silica-rich Miocene section and the surrounding sediments imply that this siliceous interval should be identifiable and traceable on seismic sections. Because of the paleoceanographic significance of enhanced biogenic silica deposition (typically associated with upwelling and high productivity), the ability to use the seismic record to map the extent of siliceous sedimentation on the Vøring Plateau can provide important new paleoceanographic data. This paper will explore

\footnotetext{
${ }^{1}$ Eldholm, O., Thiede, J., Taylor, E., et al., 1989. Proc. ODP, Sci. Results, 104: College Station, TX (Ocean Drilling Program).

2 Geologisch-Paläontologisches Institut und Museum der Universität Kiel, Olshausenstr. 40, 2300 Kiel, Federal Republic of Germany.

3 Dept. of Oceanography, Dalhousie University, Halifax B3H 4J1, Canada.

4 Ocean Drilling Program, Texas A\&M University, College Station TX 77840.

${ }_{5}$ Now at School of Oeanography, University of Washington, Seattle, WA 98195.

${ }^{6}$ Alfred-Wegener-Institut für Polar- und Meeresforschung, Columbusstr., 2850 Bremerhaven, Federal Republic of Germany.

${ }^{7}$ Dept, of Oceanography, Texas A\&M University, College Station, TX 77843.
}

the ability to seismically identify this siliceous section; a future study will address the paleoceanographic significance of its distribution. The seismic reflector notations of Jørgensen and Navrestad (1981) and Skogseid and Eldholm (this volume) are adopted for this study.

The seismic record is measured as a function of seismic travel time while the stratigraphic record is measured with respect to depth below seafloor. Knowledge of the in situ velocity vs. depth function and of the nature of the interaction of the seismic wavelet with the down-section geologic variability, is the only means to unambiguously make the transformation between the seismic and stratigraphic records. Without an exact knowledge of in situ velocities we must attempt to derive an in situ velocity vs. depth function and then use synthetic seismograms to test the veracity of our derived estimates. This is the approach we will take in attempting to evaluate our ability to seismically identify and trace the Miocene siliceous deposits on the Vøring Plateau.

\section{METHODS \\ Seismic data}

During the summer of 1985 seismic reflection data were collected aboard R/V Poseidon by the Institut für Geophysik, University of Kiel. Although over $3000 \mathrm{~km}$ of seismic data were collected on this survey (Fig. 1), this report concentrates only on the area northwest of the Vøring Plateau Escarpment in the vicinity of ODP Leg 104 Sites 642 and 643 .

The seismic data were collected using a single 0.6-L (36-in. ${ }^{3}$ ) PraklaSeismos air gun. Data were received on a 10-channel Prakla-Seismos streamer with an active length of $450 \mathrm{~m}$. The relation of streamer length to water depth prohibited data processing to achieve interval velocities. The data were amplified and then digitized at a $2.4-\mathrm{ms}$ period. A NOVA 4/X (Data General) computer was used as the control processing unit. The seismic profiles presented here are three-trace mixes of the digitized and subsequently filtered $(50-150 \mathrm{~Hz})$ data.

\section{Quantification of Biogenic Silica}

During routine shipboard analysis of smear slides, biogenic silica content is estimated. Smear-slide estimates of biogenic silica content are difficult, however, and often inaccurate (overestimate) due to the large area covered by diatoms compared to their weight. For this study, we use the quantitative measurements of weight percentage of biogenic silica made by Bohrmann (1988) on 56 samples from Site 642 and 55 samples from Site 643. 


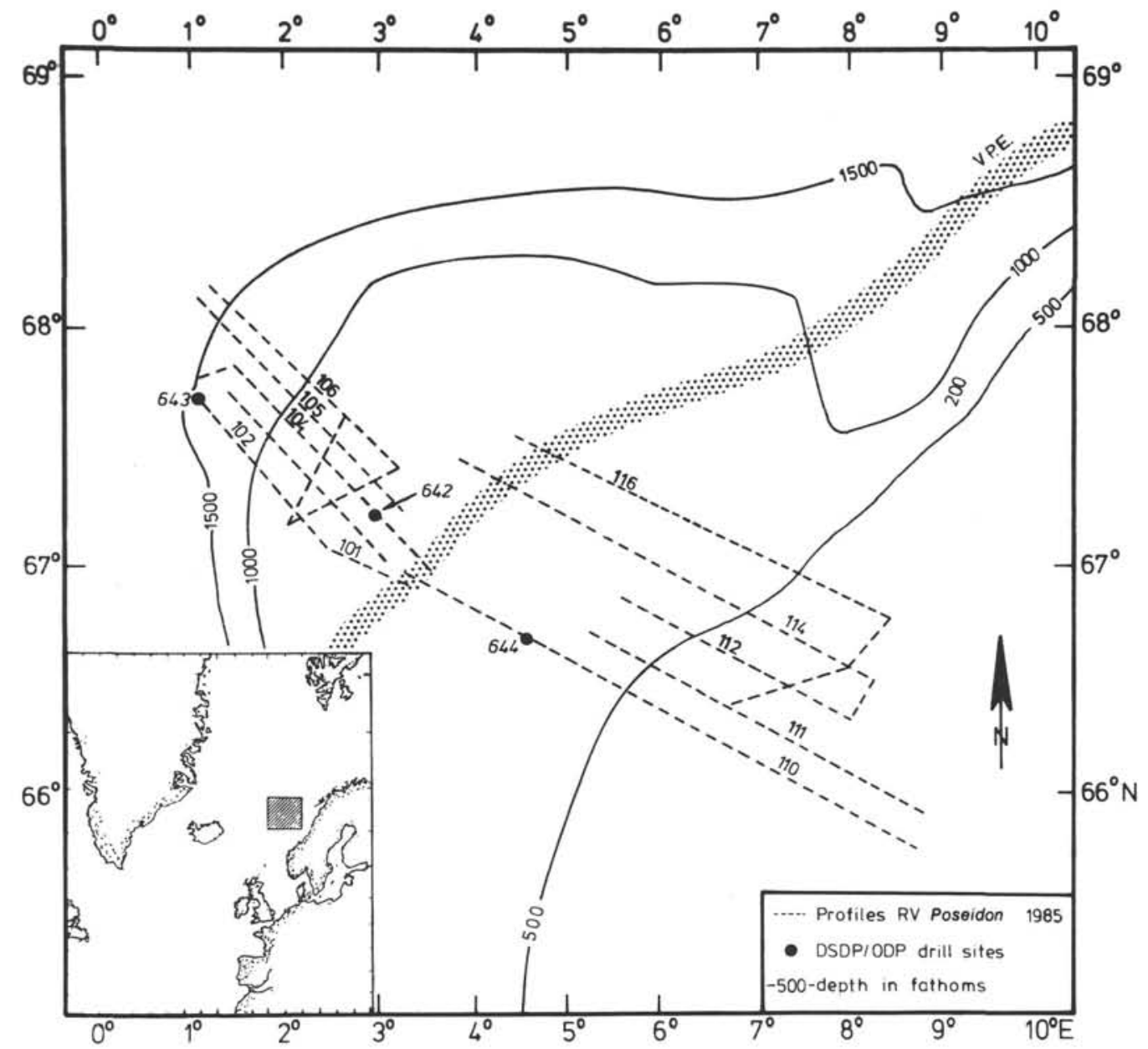

Figure 1. Location of study area in the Norwegian-Greenland Sea, including ODP drill sites and track chart of air-gun reflection seismic surveys. Profiles by Poseidon are shot using a single 0.6-L air gun. Profiles by Valdivia are shot by an air-gun array, composed of five air guns, with a total chamber volume of 5.5 L. V.P.E. is Vøring Plateau Escarpment.

\section{Shipboard Physical Properties Measurements}

During ODP Leg 104, physical properties of the sediments were measured routinely every $3 \mathrm{~m}$ on average at Site 643 (Eldholm, Thiede, Taylor, et al., 1987). The sample interval at Site 642 is somewhat smaller because this site consists of three holes in the sedimentary section, which were all sampled (Eldholm, Thiede, Taylor, et al., 1987). All saturated bulk density, grain density, porosity, and sonic velocity measurements were taken into account in this study. Measurements were carefully compared with the lithologic descriptions of the cores and those values from disturbed intervals were eliminated from the analysis. Single-point extreme values of velocity, unsupported by variations in other physical properties, were also not included in the analysis. Sixty seven values at Site 642 (to $328 \mathrm{mbsf}$ ) and 54 values at Site 643 (to $296 \mathrm{mbsf}$ ) (Figs. 2, 3) were corrected for in situ (see below) conditions and result in the saturated bulk density and sonic velocity values used for the generation of synthetic seismograms.

\section{Logging Data}

The upper sedimentary section (0-200 mbsf) was only logged at Hole $642 \mathrm{D}$ on Leg 104. Measurements included the compensated neutron, lithodensity, and sonic logs. The compensated neutron log and the lithodensity log delivered good quality, high-resolution data from a larger formation volume than that possible with laboratory physical property measurements from cored sediments. The section scanned by these two tools was 40-203 mbsf and 33-208 mbsf, respectively (Figs. 2, 3). Tool geometry, lithology, and borehole conditions are responsible for the poor data quality of the sonic log. Only the far receiver pair (3.05-
$3.66 \mathrm{~m}$ ) delivered reasonable transit-time measurements (Fig. 2, and Eldholm, Thiede, Taylor, et al., 1987). Without data from both receiver pairs, the sonic log provides only qualitative velocity information and some indication of the depth of various lithologic units.

\section{Comparison of Logging and Physical Properties Data}

A difficulty in the comparison of logs with physical property data at Site 642 is the fact that the logged sedimentary section in Hole 642D was not cored. Therefore, logging data of Hole 642D must be compared with physical property measurements of sediments from Holes 642B and $642 \mathrm{C}$.

The vertical resolution of logging data (less than $1 \mathrm{~m}$ ) is higher than that obtainable from the shipboard measurement of physical properties. In general, the logged porosity is lower than that measured in the shipboard laboratory (Figs. 2, 4). The opposite is observed for saturated bulk density and sonic velocity (Fig. 2). The differences between the logging results and physical properties measurements can be explained by expansion of the cored sediments upon retrieval from the deep-sea subbottom (removal of in situ stresses). The logging results are more representative of the in situ physical properties of the sediments than those measurements obtained on board. The difference between log and laboratory data generally increases downhole, but varies with depth of burial in each lithologic unit (Fig. 4). This is in good agreement with the findings of Goldberg et al. (1987).

\section{Conversion From Laboratory to in situ Values}

To compare the seismic section with the borehole results we must have an accurate knowledge of the in situ velocity vs. depth function. 


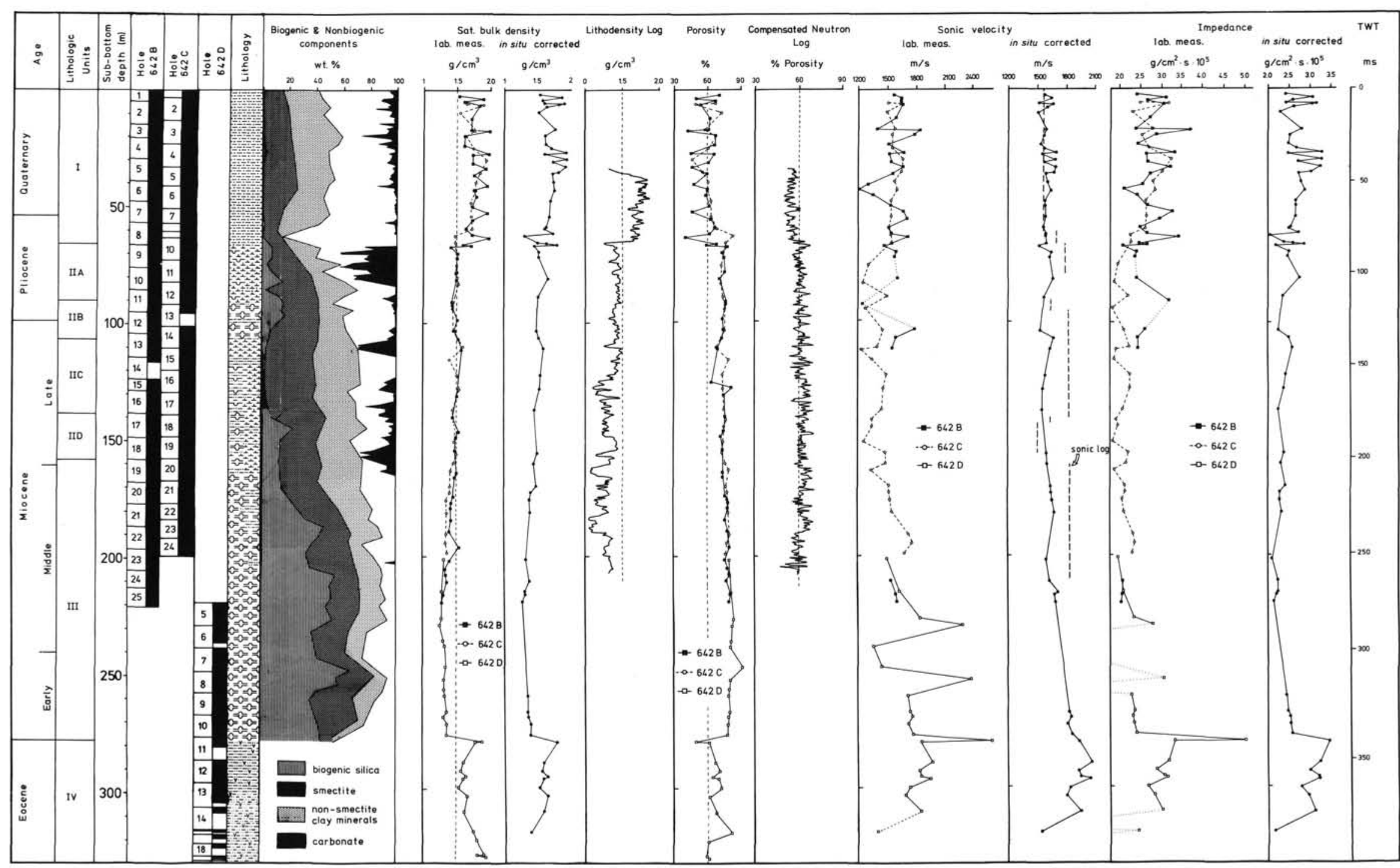

Figure 2. Site 642 lithology and shipboard physical property measurements (Eldholm, Thiede, Taylor, et al., 1987). The in-situ corrected saturated bulk density and sonic velocity result in an in-situ impedance profile vs. depth. Two-way traveltime (TWT) was calculated from corrected sonic velocities. 


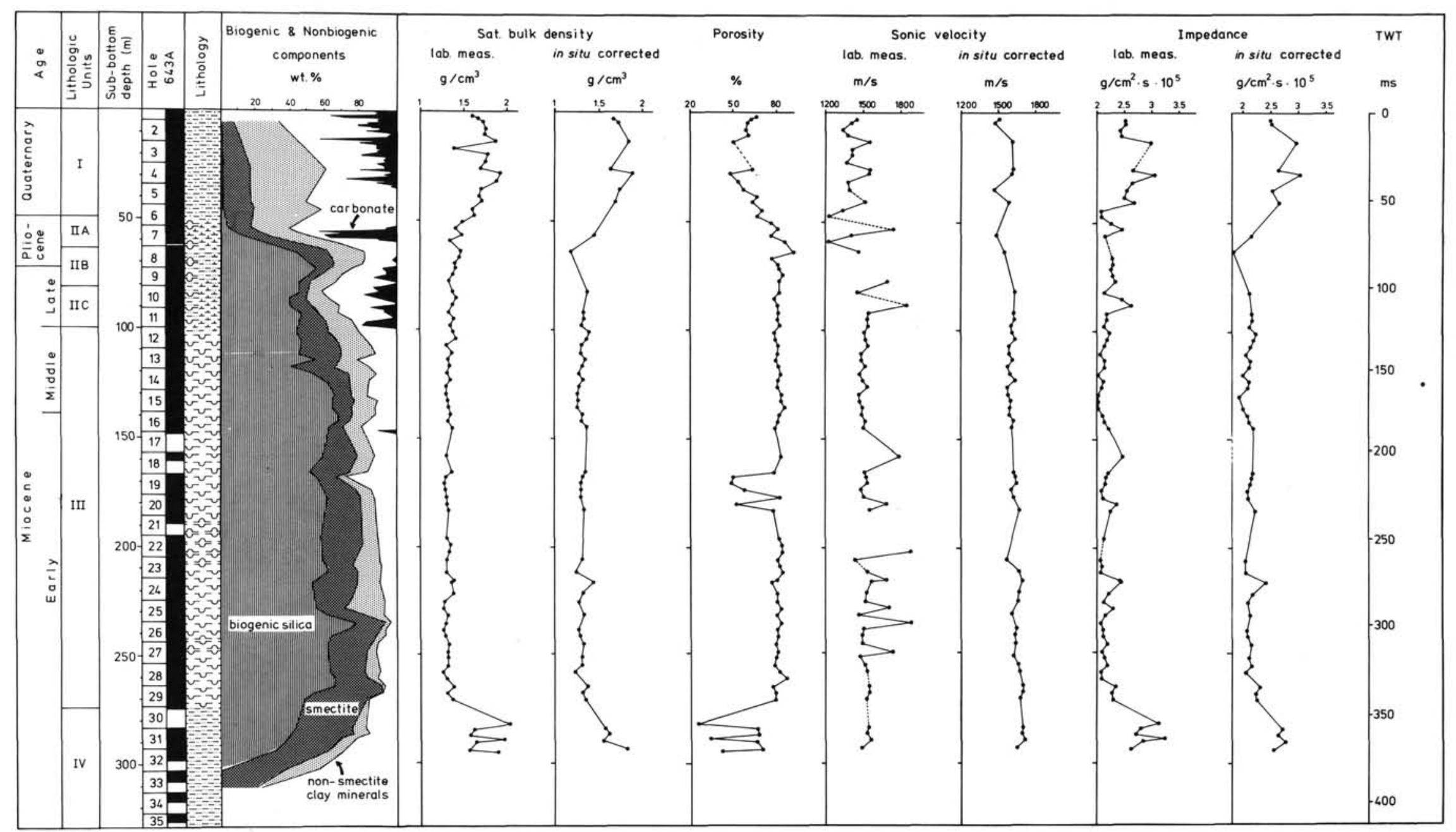

Figure 3. Site 643 lithology and shipboard physical property measurements (Eldholm, Thiede, Taylor, et al., 1987). The in-situ corrected saturated bulk density and sonic velocity result in an insitu impedance profile vs. depth. Two-way traveltime (TWT) was calculated from corrected sonic velocities. 


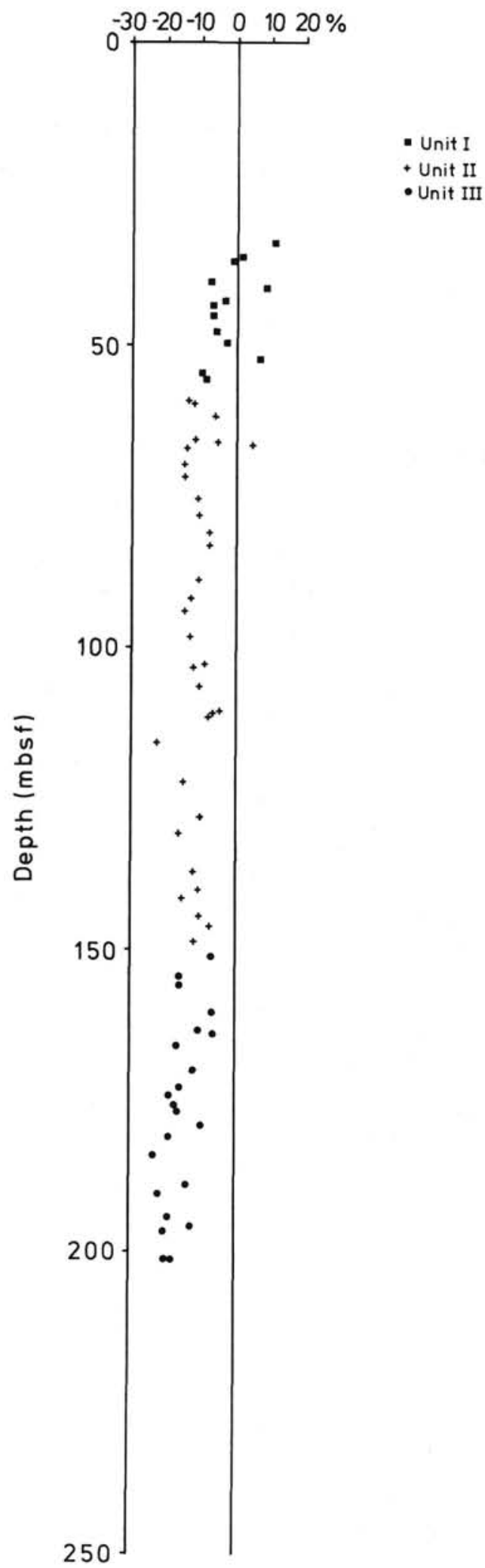

Figure 4. Porosity values from the compensated neutron log minus the laboratory-measured porosity values at Site 642 . Most values are negative because the log data represent in-situ conditions, whereas the laboratory measurements are affected by an increase in porosity as a function of rebound.
Because of the paucity of $\log$ data we corrected the laboratory measurements to in situ values. The retrieval of samples from the ocean subbottom to the shipboard laboratory is accompanied by several changes in the physical properties of the samples. Four major factors are discussed by Hamilton $(1965,1976)$ :

1. Decrease of hydrostatic pressure

2. Temperature changes

3. Increase in porosity caused by removal of overburden

4. Decrease in rigidity

These factors must be accounted for to correct laboratory measurements to in situ conditions. Saturated bulk density and sonic velocity, the controlling sediment parameters for seismic propagation, are both affected by these changes; however, sonic velocity is affected to a much greater degree than density. Of the factors mentioned above, the increase in porosity caused by removal of overburden pressure has the most significant effect (Boyce, 1976; Hamilton, 1979; Mayer et al., 1985). In this study, the decrease of rigidity has not been accounted for because of difficulties in quantifying its influence on density and sonic velocity. However, numerous studies (Boyce, 1976; Hamilton, 1979; Mayer et al., 1985) have demonstrated that this effect is minimal.

The Site 642 sediment column was subdivided into two sections for the correction procedure. A depth of $182 \mathrm{mbsf}$ was chosen to separate the predominantly terrigenous unit from the diatomaceous unit, because at this depth the biogenic silica content increases from less than $30 \%$ to well above $50 \%$ at Site 642 (Fig. 2). Physical properties data of sediments in the depth interval $0-182$ mbsf were corrected using Hamilton's (1976) equations for porosity rebound in terrigenous sediments, and measurements in the depth interval of 182-275 mbsf were corrected using his equation for rebound in diatomaceous mud.

The calculated porosity rebound for diatomaceous sediments is between 3 and $4 \%$, resulting in a minimal absolute increase of porosity at a depth of $300 \mathrm{mbsf}$. This small porosity increase is caused by the ability of diatoms to maintain their open structure at the ambient pressure. The high porosity throughout the entire section of diatomaceous mud is also a result of this phenomenon (Figs. 2, 3). The increase of porosity with depth within the siliceous unit at Site 642 is clearly related to the increasing percentage of biogenic silica (Fig. 2).

Because of the linear relationship between saturated bulk density and porosity (Fig. 5), a rebound correction can easily be applied to the saturated bulk density values measured in the shipboard laboratory. Densities have been calculated using the equation given by Boyce (1976):

$$
\sigma_{\text {is }}=\sigma_{\mathrm{w}} \phi+(1-\phi) \sigma_{\mathrm{g}}
$$

where

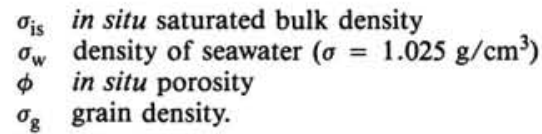

Sonic velocity is also affected by variations in temperature and pressure. To correct for these effects, profiles of in situ temperature and pressure must be established. The temperature profile was estimated from results of downhole temperature measurements at Hole $642 \mathrm{C}$ and calculations on the temperature gradient from logged resistivity data at Hole 642D (Eldholm, Thiede, Taylor, et al., 1987). The published thermal gradient in this region is $85^{\circ} \mathrm{C} / \mathrm{km}$, starting at a bottom-water temperature on the Vøring Plateau of $-0.92^{\circ} \mathrm{C}$ to $-0.84^{\circ} \mathrm{C}$ at Sites 643 and 642, respectively (Gerlach et al., 1986). As detailed information on the thermal gradient at Site 643 is lacking, we used the Site 642 gradient values for both sites. Procedures and assumptions for temperature and pressure corrections of sonic velocity are described by Mayer et al. (1985).

\section{RESULTS}

\section{Seismic modeling}

The corrected saturated bulk densities and sonic velocities were used to calculate an acoustic impedance profile as a function of depth, and the corrected velocity values were used to cal- 


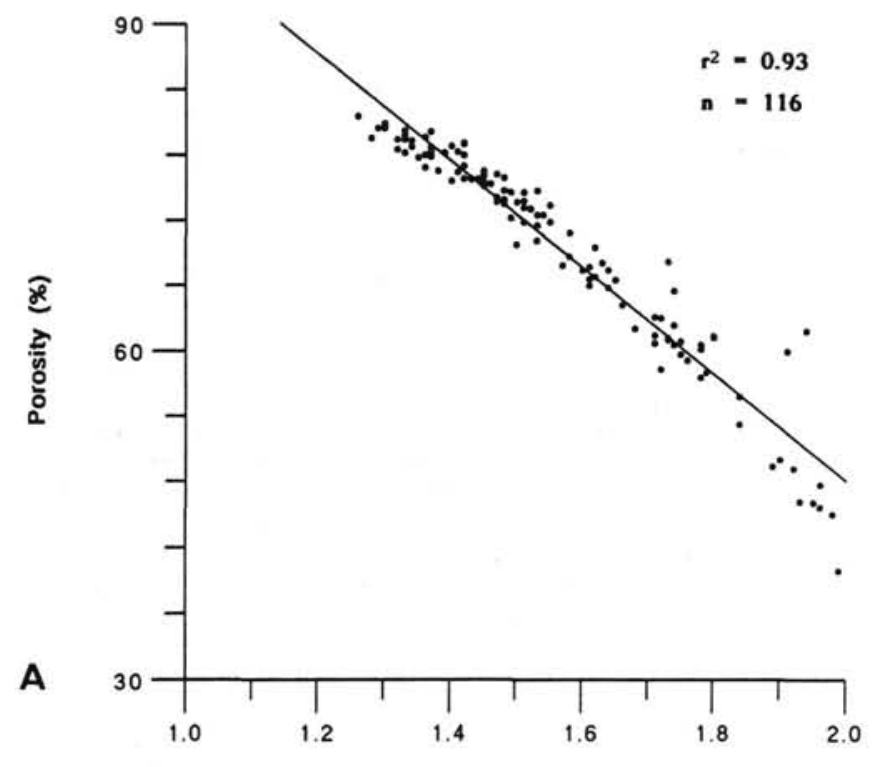

Sat. Bulk Density $\left(\mathrm{g} / \mathrm{cm}^{3}\right)$

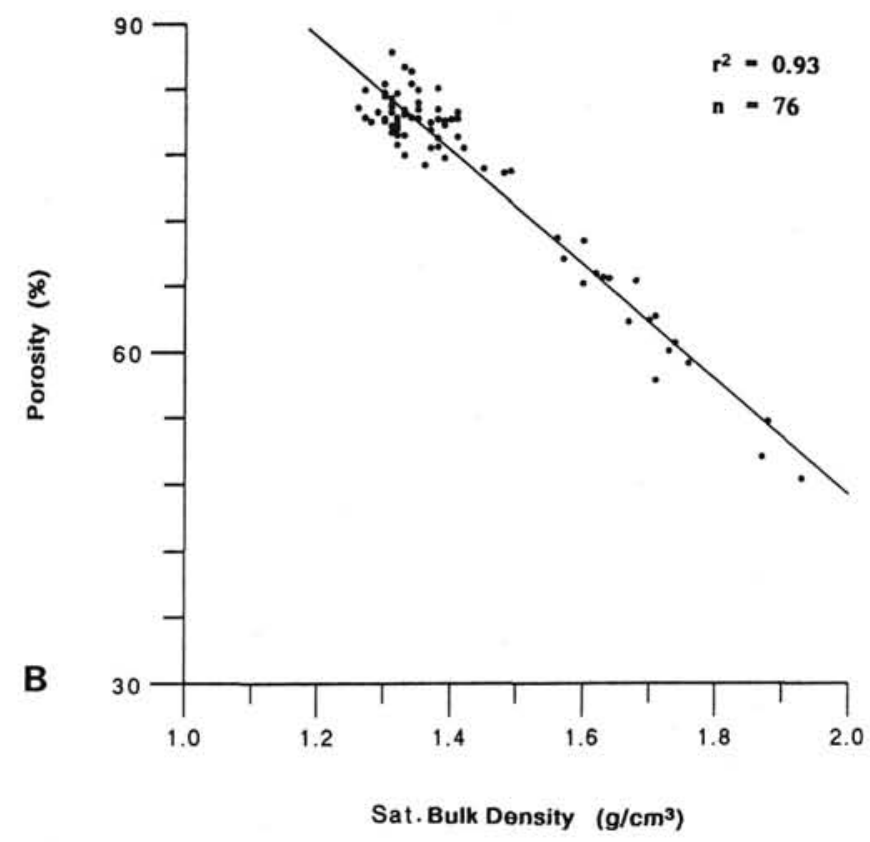

Figure 5. Regression of porosity against saturated bulk density at (A) Site 642 , and (B) Site $643 . r^{2}=$ regression coefficient, $n=$ no. of samples.

culate impedance as a function of traveltime (Figs. 2, 3). The impedance curve was resampled at the same interval $(2.4 \mathrm{~ms})$ as the field seismogram and then used to compute a downhole reflection coefficient log (Fig. 6). The reflection coefficient log was convolved with the measured outgoing wavelet of the field equipment to generate synthetic seismograms for Sites 642 and 643 (Figs. 10, 11). The synthetic seismograms were filtered with the same filters as the field records $(50-150 \mathrm{~Hz}$ bandpass) and then displayed at the same scale as the field record. Synthetic seismograms were generated with the software of Mayer et al. (1985) which assumes plane waves and does not include multiple paths or attenuation.

\section{Biogenic Silica and Seismic Reflectors}

Biogenic silica is characterized by generally low grain density (e.g., Hurd, 1983), with density values for diatom frustules ranging between 1.98 and $2.01 \mathrm{~g} / \mathrm{cm}^{3}$. Low grain densities are caused by an amorphous mineralogical structure comprised of crystal water $\left(\mathrm{SiO}_{2} \cdot \mathrm{H}_{2} \mathrm{O}\right)$ and by the numerous skeletal pores (Hurd, 1983 , and references therein). Additionally, diatom tests are very open structures, the net result being the high porosity values seen in diatom-rich sediments. The close relationship at Site 643 between high amounts of biogenic silica and low grain density is shown in Figure 7. Other geotechnical properties also reflect the anomalous nature of these extremely underconsolidated diatom-rich sediments (Pittenger et al., this volume).

The influence of the low grain densities and high porosities of biogenic silica is clearly evident in the low saturated bulk densities of the Miocene sections of Sites 642 and 643. While the decrease in saturated bulk density associated with increased silica content also exerts an influence on the sonic velocity of the sediment (typically a decrease in velocity), the magnitude of this effect (as a percentage of the mean value of velocity) is small. Therefore, the acoustic impedance of the Miocene biogenic silica-rich sediments is markedly lower than that of the biogenic silica-free sediments above or below. Linear regressions of saturated bulk density and velocity against acoustic impedance for Sites 642 and 643 (Figs. 8,9) reveal that variations of saturated bulk density have a stronger influence on acoustic impedance than velocity. If the acoustic impedance contrast is sharp enough, we would expect to find a seismic reflector with negative polarity associated with the upper boundary of biogenic silica-rich sediments and a normal polarity reflection associated with the lower boundary.

While the sampling of physical properties at Sites 642 and 643 is by no means continuous enough to allow a detailed comparison of the seismic and borehole records, we examine the major lithologic and seismic features in an attempt to evaluate the usefulness of the seismic record for paleoceanographic analysis. We describe the major lithologic features at each site and then use the traveltime-depth conversions we have established along with our synthetic seismograms to interpret the seismic expression of these lithologic variations.

\section{Site 642}

Site 642 has been divided into four lithologic units (Fig. 2).

Unit I (0-60 mbsf; late Pliocene to Holocene) is dominated by clastic components and non-smectite clay minerals of repeatedly alternating sandy muds and muds (Eldholm, Thiede, Taylor, et al., 1987). This results in alternating, but generally high, saturated bulk density, low porosity values, and variable sonic velocity values.

Unit II (60-159 mbsf; middle Miocene to late Pliocene) is characterized by: (a) highly variable carbonate content, (b) the first appearance of biogenic silica, and (c) consistently high amounts of smectite. Smectite data are taken from Froget et al. (this volume). Saturated bulk density is generally low in Unit II, correlating with high porosity values. Sonic velocity is highly variable and decreases slightly toward the base.

Unit III (159-276 mbsf; early Miocene to middle Miocene) has replacement of carbonate- and clastic-rich deposits by biogenic silica-rich deposits, consisting predominantly of diatoms. The clay fraction is still dominated by smectite. A slight decrease of saturated bulk density is observed, mirrored by increased porosity, whereas sonic velocity values are higher than 
SITE 642

\section{Reflection coefficient Reflection coefficient}

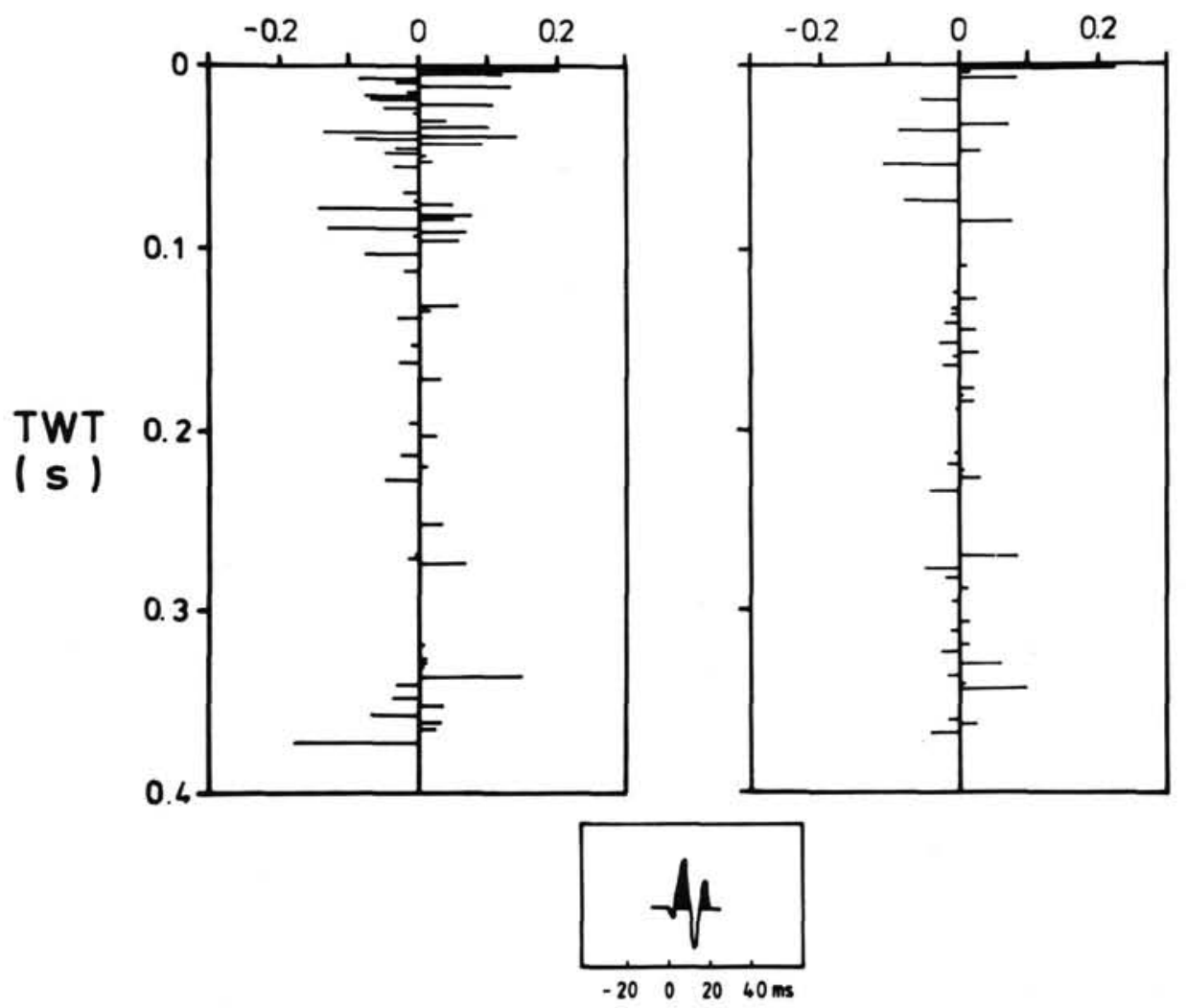

Figure 6. Reflection coefficient vs. two-way traveltime at Site 642 and Site 643 . The wavelet of the outgoing pulse of the field equipment is also displaced.

those in Unit II. In the absence of reliable sonic velocity measurements in the depth range of 218-267 mbsf, no acoustic impedances could be calculated. However, the lack of variability in the saturated bulk density values over this depth range implies low variability in acoustic impedance. At the base of Unit III the transition from lower Miocene diatomaceous mud to lower Eocene volcaniclastic mudstones results in a drastic change in the physical properties of the recovered sediments, with a sharp downhole increase in both saturated bulk density and sonic velocity.

The cyclic variations in density and velocity associated with glacial/interglacial depositional changes result in a series of closely spaced reflectors (Figs. 2, 10). The lithologic changes at the Unit I/Unit II boundary are marked by a prominent seismic event (Figs. 2, 10). A strong reflector at $87 \mathrm{~ms}$ TWT (67 mbsf) on both the synthetic and the field records correlates with the sudden onset (downsection) of carbonate-rich sediments. Thus at Site 642 the major change in paleoceanographic conditions associated with the change from biogenic silica and carbonate deposition to clay-dominated deposition is seismically clearly identifiable.

The transition from Unit II to III is marked by the disappearance of carbonate and increasing biogenic silica abundance (Fig. 2). A moderate-amplitude reflector is seen on the field record at this level (204 ms TWT; $160 \mathrm{mbsf}$ ) as well as a low-amplitude reflector on the synthetic record (Fig. 10). Within Unit
III several low-amplitude reflectors (e.g., at $287 \mathrm{~ms} / 230 \mathrm{mbsf}$ ) appear to correlate with fluctuations in biogenic silica content but our resolution of these events is not sufficient to produce unambiguous correlations.

The change from lower Miocene diatomaceous mud to lower Eocene volcaniclastic sediments at the Unit III/Unit IV transition is expressed as a series of high-amplitude reflectors on both the synthetic and field records (Fig. 10). The top of Unit IV is formed by a hardground underlain by volcanic ash, causing a strong fluctuation in the reflection coefficient profile (Fig. 6). The acoustic impedance contrast at 277.6 mbsf (347 ms TWT) produces the reflector " $A$ " which can be correlated with a lower Miocene unconformity (Skogseid and Eldholm, this volume). This unconformity, coincident with lithologic Unit III/IV transition, can be traced over the entire Vøring Plateau (Skogseid and Eldholm, this volume). Interpretations of seismic lines by Caston (1976), Hinz et al. (1984), and Mutter (1984), supported by drilling results of DSDP Site 338 (Talwani, Udintsev et al., 1976) correlated the reflector with a mid-Oligocene unconformity. Eldholm, Thiede, Taylor, et al. (1987) suggest that the unconformity at Site 338 could be analogous to the lower Miocene unconformity at Site 642 by nondeposition of Oligocene and upper Eocene sediments at some parts of the Vøring marginal high.

The slight mismatch in the depths of the reflectors in the synthetic and the field seismogram (approx. $8 \mathrm{~ms}$ or $6 \mathrm{~m}$ ) is the 


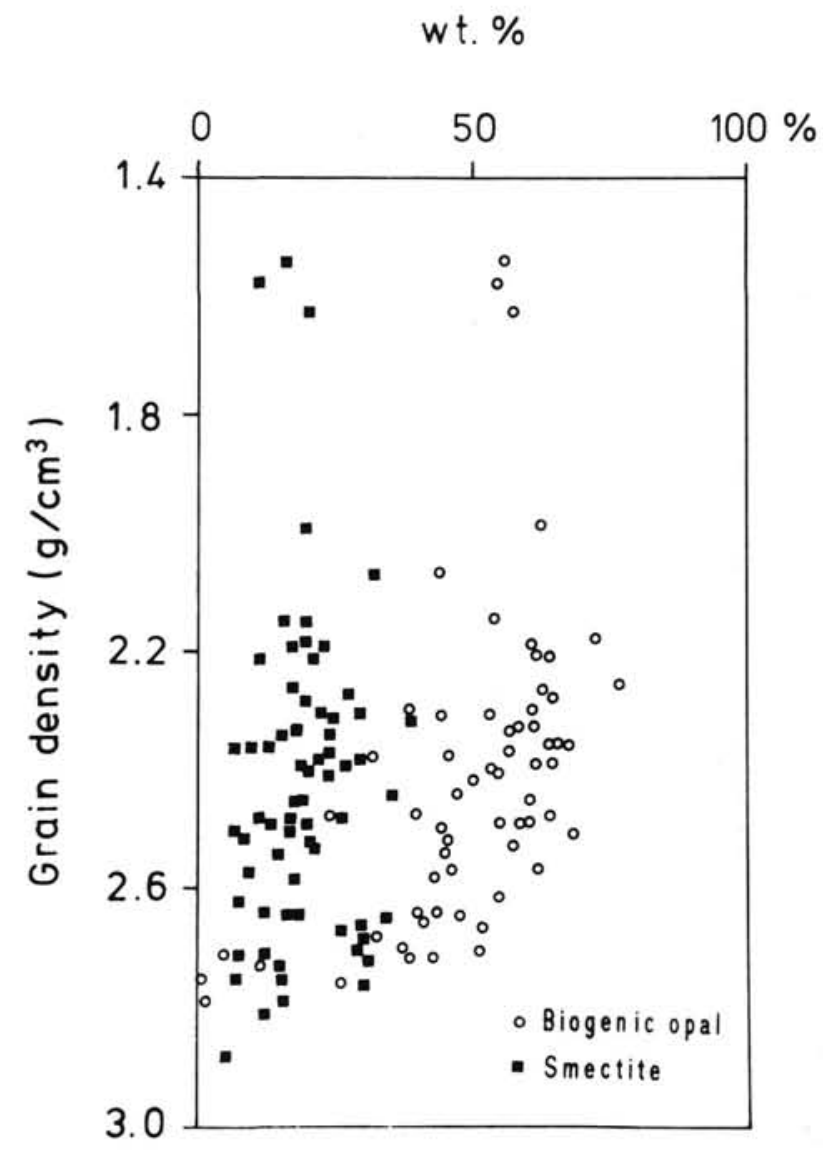

Figure 7. Biogenic opal and smectite vs. grain density, Site 643 . The grain density is representative for the entire sample in which biogenic silica and smectite is measured. Note samples with high $(>50 \%)$ biogenic silica content have grain densities of $2.2-2.6 \mathrm{~g} / \mathrm{cm}^{3}$ with decreasing bulk density corresponding to increasing silica. Smectite-rich samples are represented by grain densities of $2.2-2.7 \mathrm{~g} / \mathrm{cm}^{3}$. The values around 1.5 $\mathrm{g} / \mathrm{cm}^{3}$ most likely represent incorrect measurements.

result of the propagating error associated with an inexact velocity-depth conversion function. Nonetheless, the seismic identification of the base of Unit III is unambiguous.

The Unit IV/V boundary at 315 mbsf (Eldholm, Thiede, Taylor, et al., 1987) is expressed in the seismograms as a strong reflector at $388 \mathrm{~ms}$ TWT. This reflector, called "EE" (Skogseid and Eldholm, this volume), originates from the top of the lower Eocene volcanic sequence.

\section{Site 643}

Sediments recovered at Site 643 (Fig. 3) indicate a more pelagic depositional environment throughout the Neogene and Quaternary. Therefore physical property values are less variable than those observed at Site $\mathbf{6 4 2}$. Unit I is dominated by terrigenous material consisting primarily of fine-grained sediments like muds, sandy muds, and calcareous sandy muds (Eldholm, Thiede, Taylor, et al., 1987). This upper unit is a 50-m-thick sequence of glacial-interglacial sedimentary cycles, characterized by repeated alternations of carbonate-poor and carbonate-rich layers. Shipboard physical property measurements on split samples are too widely spread to resolve individually alternating layers. Like Site 642 , Unit I is characterized by generally high saturated bulk densities, low porosities, and fluctuations in sonic velocity that reflect the lithologic alternations. Toward the base of Unit I, saturated bulk density gradually decreases and porosity increases,
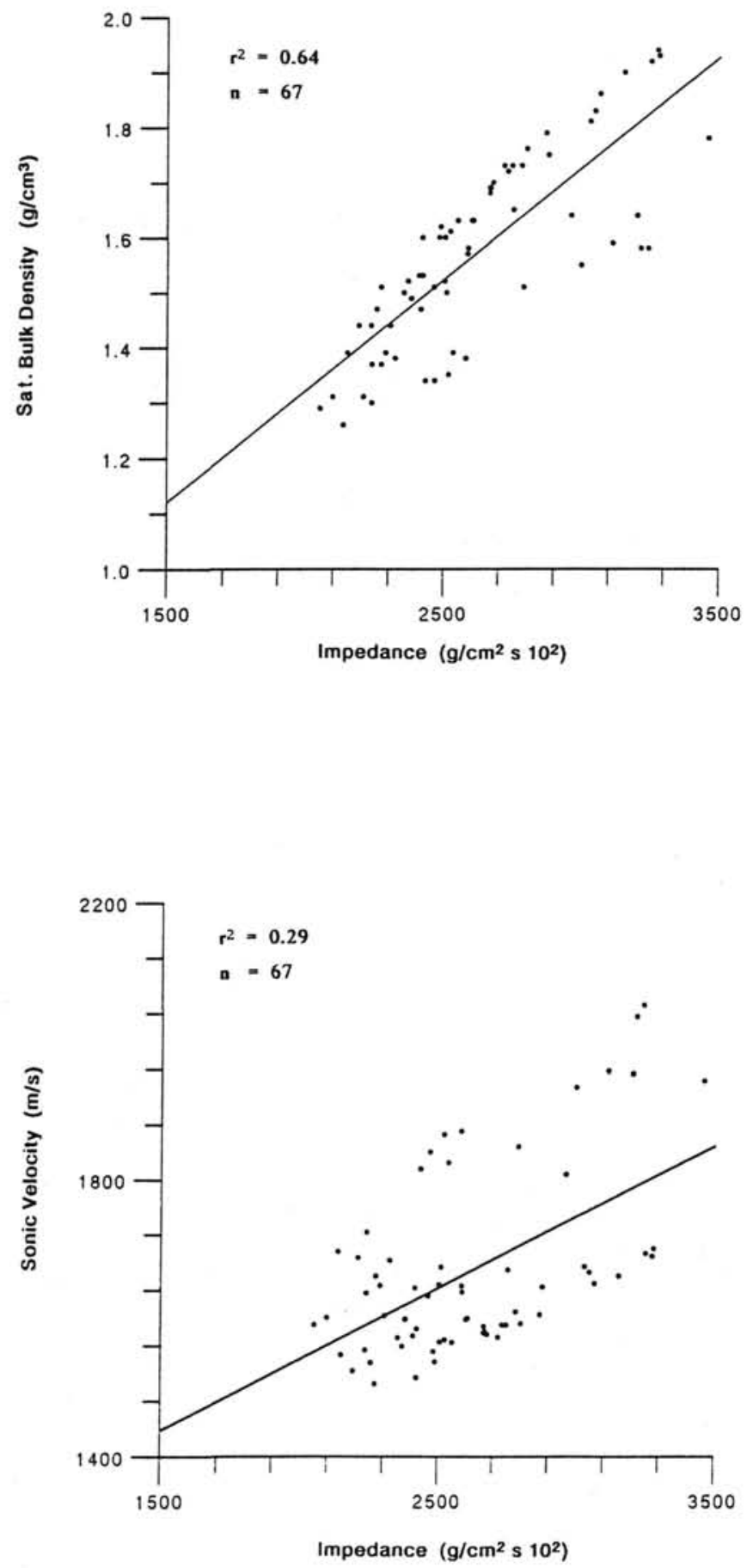

Figure 8. Correlation of in-situ corrected saturated bulk density, sonic velocity, and acoustic impedance at Site $642 \cdot r^{2}=$ regression coefficient, $\mathrm{n}=$ no. of samples.

probably the result of the increasing presence of even small amounts of biogenic silica.

The transition from Unit I to Unit II is marked by two carbonate-rich layers (in the upper Pliocene) and the downcore onset of biogenic silica as the dominant sediment component. Apart from biogenic silica and various amounts of carbonate, an increasing amount of smectite within the clay fraction is observed (Froget et al., this volume). Smectite is fairly important for the discussion of physical property data. A closer look at 

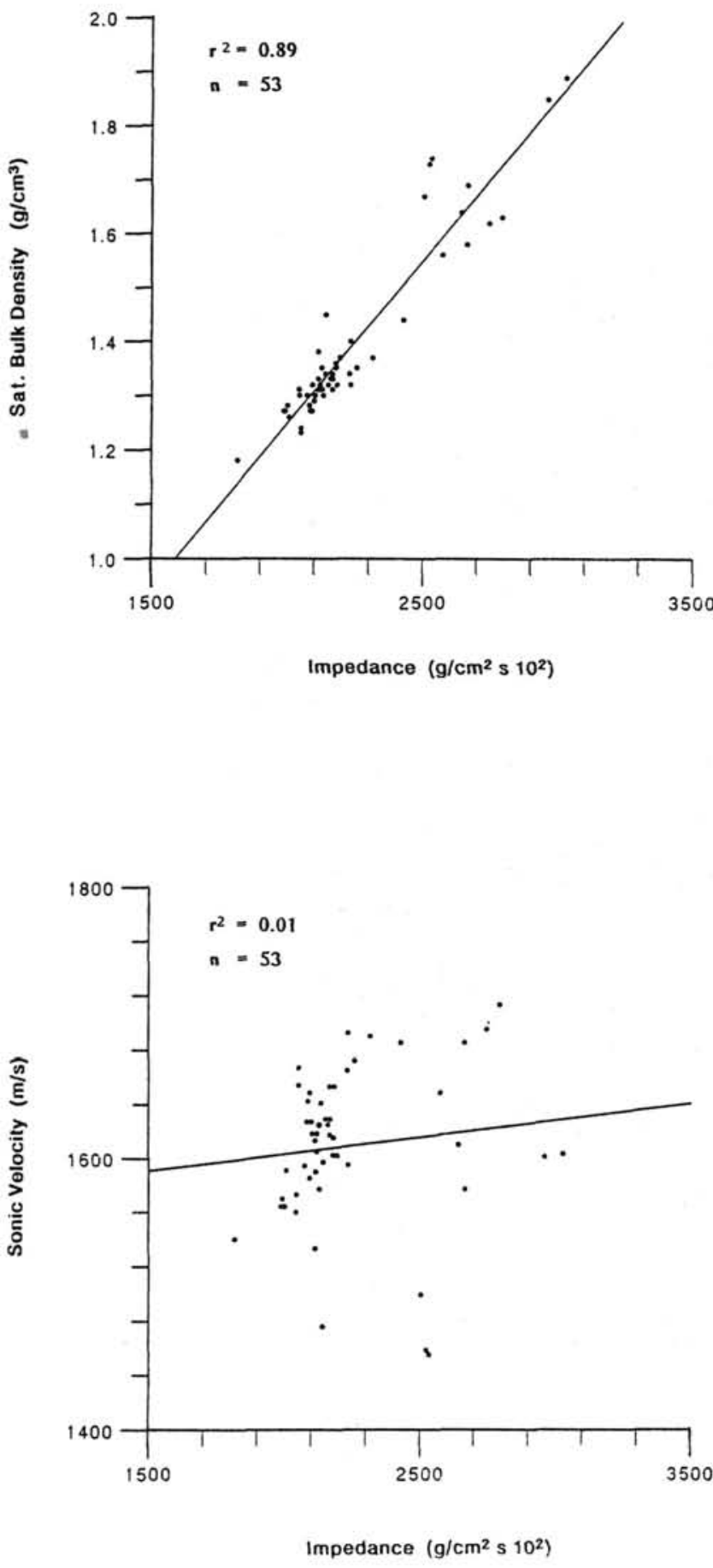

Figure 9. Correlation of in-situ corrected saturated bulk density and sonic velocity with acoustic impedance at Site $643 . \mathrm{r}^{2}=$ regression coefficient, $\mathrm{n}=$ no. of samples.

the relationship between grain density and smectite shows that smectite-rich sediments of Site 643 are defined by an apparent bimodal grain density distribution (Fig. 7, modes around $2.3 \mathrm{~g}$ / $\mathrm{cm}^{3}$ and $2.7 \mathrm{~g} / \mathrm{cm}^{3}$ ). As a sheet silicate, smectite is able to absorb large quantities of water, and thus the section of high smectite mineral abundances and siliceous-rich sediment is highly water saturated.

Unit III has high abundances of biogenic silica and smectite throughout, decreasing rapidly at the boundary with Unit IV.
At the transition with Unit IV, saturated bulk density increases as porosity decreases. Sonic velocities remain constant at this transition, despite the fact that Unit IV consists of compacted mudstones (Eldholm, Thiede, Taylor, et al., 1987). In Unit IV biogenic silica (opal-A) is replaced by the diagenetically transformed opal-CT, reaching its maximum value at $414 \mathrm{mbsf}$ (Unit V) (Bohrmann, 1988).

The seismic expression of the glacial/interglacial alternating layers of Unit I is a series of closely spaced reflectors similar to those found at Site 642 , though much less pronounced probably due to the pelagic nature of the Site 643 deposits. The agreement between the field and synthetic records in this interval is excellent, though, as at Site 642 , no one-to-one correlation can be drawn between the seismic events and the lithology.

The decrease in acoustic impedance within lithologic Subunit IIA ( $60 \mathrm{mbsf}$ ) is produced by the sudden downhole onset of biogenic silica. This change results in a negative polarity reflection at $75 \mathrm{~ms}$ in the synthetic seismogram (Figs. 2, 11) and can be correlated with the field record. This reflector corresponds to the base-Pliocene reflector " $O$ " (Jørgensen and Navrestad, 1981) or reflector "UP" after Skogseid and Eldholm (this volume). The reflector at the Subunit IIB/IIC boundary (Fig. 11) reflects the relatively low amount of biogenic silica $(40 \%)$ compared to $60 \%$ in Subunit IIB (Fig. 3). The sequence of reflectors in the depth range of Subunits IIA through IIC in the synthetic seismogram is in good agreement with the field record and indicative of the variations in biogenic carbonate and silica content. Reflectors produced in the synthetic seismogram within Unit III can not be correlated with the field record.

The Unit III/IV transition at $348 \mathrm{~ms}(296 \mathrm{~m})$ is characterized by a series of strong reflectors culminating $28 \mathrm{~ms}(24 \mathrm{~m})$ below the boundary in a very strong reflector, situated $3 \mathrm{~m}$ below the deepest sample containing biogenic silica. Following the Skogseid and Eldholm (this volume) nomenclature, this reflector is called " $\mathrm{A}$ ", marking the lower Miocene. Lithologies observed in Unit IV indicate a completely different depositional environment and suite of physical properties. The correlation of the strong Unit IV reflection has an offset of about $10 \mathrm{~ms}$ (ca. $8 \mathrm{~m}$ ) between the synthetic and the field record. This is due to the propagating depth/time conversion error and to uncertainties in the location of the profile with respect to the borehole. As at Site 642 , however, the base of the siliceous unit can be unambiguously identified on the seismic record.

\section{CONCLUSIONS}

Through the use of a combination of lithostratigraphic and physical property analyses we have been able to seismically identify a well-dated, paleoceanographically significant, biogenic silica-rich deposit on the Vøring Plateau. This approach has been successful because: (a) the drill sites were continuously cored, and physical properties of the recovered sediments were routinely measured; (b) high-resolution multichannel seismic profiles were run over the drill sites; and (c) the thick section of biogenic silica-rich deposits are bounded with lithologies of completely different physical property characteristics.

The goal of seismic lithostratigraphy is the correlation of seismic data with lithologic changes revealed in the borehole. This correlation means a transformation of time-domain information into a depth-domain record which requires an accurate knowledge of the in-situ density and velocity structure of the ocean subbottom. In boreholes for which lithodensity and sonic logs are run, carefully calibrated logs can result in good estimates of in-situ conditions. In situations where no logs exist or where the logs have failed, empirically-derived means of converting laboratory-determined density and sonic velocity values to in-situ values have to be applied. 


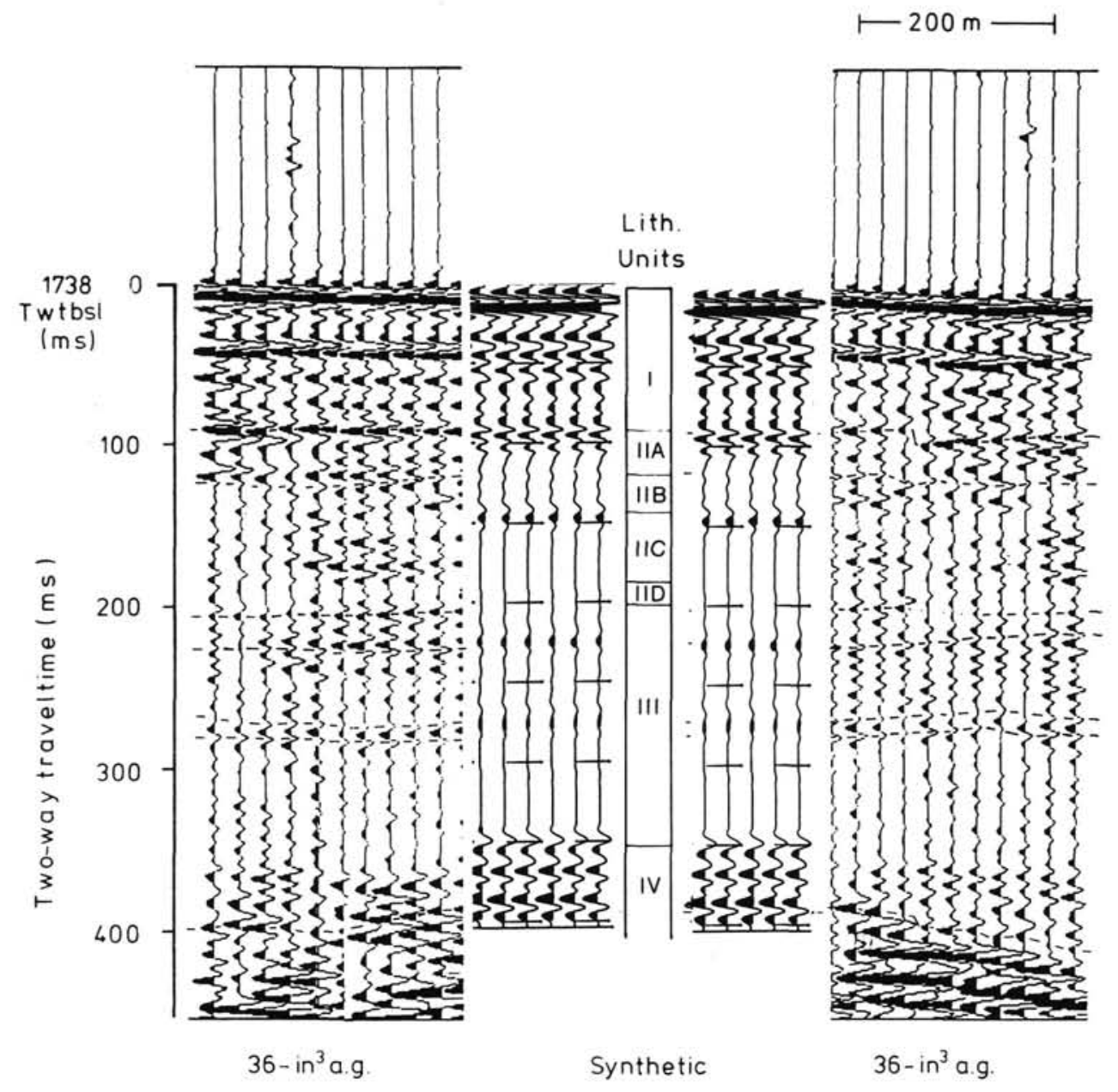

Figure 10. Comparison of the field record with the synthetic seismogram and lithologic units at Site 642 . a.g. = air gun. Data are filtered $(50-150 \mathrm{~Hz})$ and the amplitude is linearly amplified by a factor of four.

The transition from glacial/interglacial deposits with high saturated bulk densities to a biogenic silica-rich section, characterized by low saturated bulk densities causes a sharp decrease in acoustic impedance. Saturated bulk density is the controlling sediment parameter for changes in acoustic impedance at Sites 642 and 643 . The decrease in acoustic impedance produced by the low saturated bulk density values of the biogenic silica-rich sediments results in a negative polarity reflection at the upper boundary of siliceous sedimentation (reflector "O") and a positive polarity reflector at the lower boundary (reflector " $\mathrm{A}$ "). $\mathrm{Bi}$ ogenic silica-rich sediments are associated with smectite, a clay mineral with low grain density, which supports the decrease of the saturated bulk density. Several reflectors within the biogenic silica-rich unit have also been the upper and lower unit boundary reflectors; they appear to be related to fluctuations in the relative percentages of biogenic silica and carbonate.

Despite a less than continuous record of physical property measurements, we have been able to establish that the appearance and disappearance of biogenic silica-rich sediments can be identified in the seismic records from ODP Sites 642 and 643. Provided with more closely spaced physical property measurements or good, continuous logs, more detailed correlations with depositional events could have been drawn. Nonetheless, the results of this study lay the groundwork for the mapping of those reflectors associated with biogenic silica over the entire Vøring Plateau. Mapping the regional extent and thickness of this Miocene deposit will provide important new information on the pa- leoceanography of highly productive waters (Hempel, in press), and possibly about upwelling in this region.

\section{ACKNOWLEDGMENTS}

We would like to thank the crews of the JOIDES Resolution and Poseidon for their great assistance in collecting data. P. H. would like to thank P. Bugden for assistance with the synthetic seismograms, A. Schröder for drafting assistance, B. Hintz for handling the digitized field data, and C. Wieger for programming. S. Pfirman and W. Kallerhoff thoroughly read the manuscript; this is gratefully acknowledged. We very much appreciated the critical comments of O. Eldholm and A. Solheim, which significantly improved the paper.

\section{REFERENCES}

Bohrmann, G., 1988. Zur Sedimentationsgeschichte von biogenem Opal im nördlichen Nordatlantik und dem Europäischen Nordmeer (DSDP/ ODP Bohrungen 408, 642, 643, 646, \& 647). [Ph. D dissert.]. Kiel Univ., F.R.G. Ber. Sonderforschungsbereich, 313, No. 9.

Boyce, R. E., 1976. Sound velocity-density parameters of sediment and rock from DSDP drill Sites $315-318$ on the Line Island Chain, Manihiki Plateau and Tuamotu Ridge in the Pacific Ocean. In Schlanger, S. O., Jackson, E. D., et al., Init. Repts. DSDP, 33: Washington (U.S. Govt. Printing Office), 695-728.

Caston, V.N.D., 1976. Tertiary sediments of the Vøring Plateau, Norwegian Sea, recovered by Leg 38 of the Deep Sea Drilling Project. In Talwani, M., Udintsev, G., et al., 1976. Init. Repts, DSDP, 38: Washington (U.S. Govt. Printing Office), 761-782.

Eldholm, O., and Windisch, C. C., 1974. Sediment distribution in the Norwegian-Greenland Sea. Bull. Geol. Soc. Am., 85:1661-1676. 
Eldholm, O., Thiede, J., Taylor, E., et al., 1987. Proc. ODP, Init. Repts., 104: College Station, TX (Ocean Drilling Program).

Gerlach, S. A., Thiede, J., Graf, G., and Werner, F., 1986. Forschungsschiff Meteor, Reise 2 vom 19. Juni bis 16. Juli 1986. Ber. Sonderforschungsbereich, 313: No. 4, Univ. Kiel.

Goldberg, D., Wilkens, R. H., Moos, D., 1987. Seismic modeling of diagenetic effects in Cenozoic marine sediments at DSDP Sites 612 and 613. In Poag, C. W., Watts, A. B., et al., Init. Repts. DSDP, 95: Washington (U.S. Govt. Printing Office), 589-599.

Hamilton, E. L., 1965. Sound speed and related physical properties of sediments from experimental Mohole (Guadalupe Site). Geophysics, 30: $257-261$

1976. Variations of density and porosity with depth in deep sea sediments. J. Sediment. Petrol., 46: 280-300.

1979. Sound velocity gradients in marine sediments. J. Acoust. Soc. Am., 65:909-922.

Hemple P., in press. Der Einfluss von biogenen Opal auf die Bildung seismiches Reflektoren und die Verlereitung opalreicher Sedimente auf dem Vøring Plateau. [Ph.D. dissert.]. Kiel Univ., F.R.G. Ber. Sonderforsch.-bereich.

Hinz, K., Dostmann, H. J., and Hanisch, J., 1984. Structural elements of the Norwegian Sea continental margin. Geol. Jahrb., A75, 193211.
Hurd, D. C., 1983. Physical and chemical properties of siliceous skeletons. In Aston, S. R. (Ed.), Silicon geochemistry and biogeochemistry: London (Academic Press).

Jørgensen, F., and Navrestad, T., 1981. The geology of the Norwegian shelf between $62^{\circ} \mathrm{N}$ and the Lofoten Islands. In Illing, L. V., and Hobson, G. D. (Eds.), Petroleum geology of the continental shelf of NW Europe: London (Institute of Petroleum), 407-413.

Mayer, L.A., Shipley, T. F., Wilkens, R. H., and Winterer, E., 1985. Seismic modelling and paleoceanography at DSDP Site 574. In Mayer, L. A., Theyer, F., et al. Init. Repts. DSDP, 85: Washington (U.S. Govt. Printing Office), 947-970.

Mutter, J. C., 1984. Cenozoic and late Mesozoic stratigraphy and subsidence history of the Norwegian Margin. Bull. Geol. Soc. Am., 95: $1135-1149$.

Sellevoll, M. A., 1975. Seismic refraction measurements and continuous seismic profiling on the continental margin off Norway between $60^{\circ} \mathrm{N}$ and $69^{\circ} \mathrm{N}$. Norges geol. Unders., 316:219-235.

Talwani, M., Udintsev, G., et al., 1976. Init. Repts. DSDP, 38: Washington (U.S. Govt. Printing Office).

Date of initial receipt: 23 March 1988

Date of acceptance: 29 August 1988

Ms 104B-200

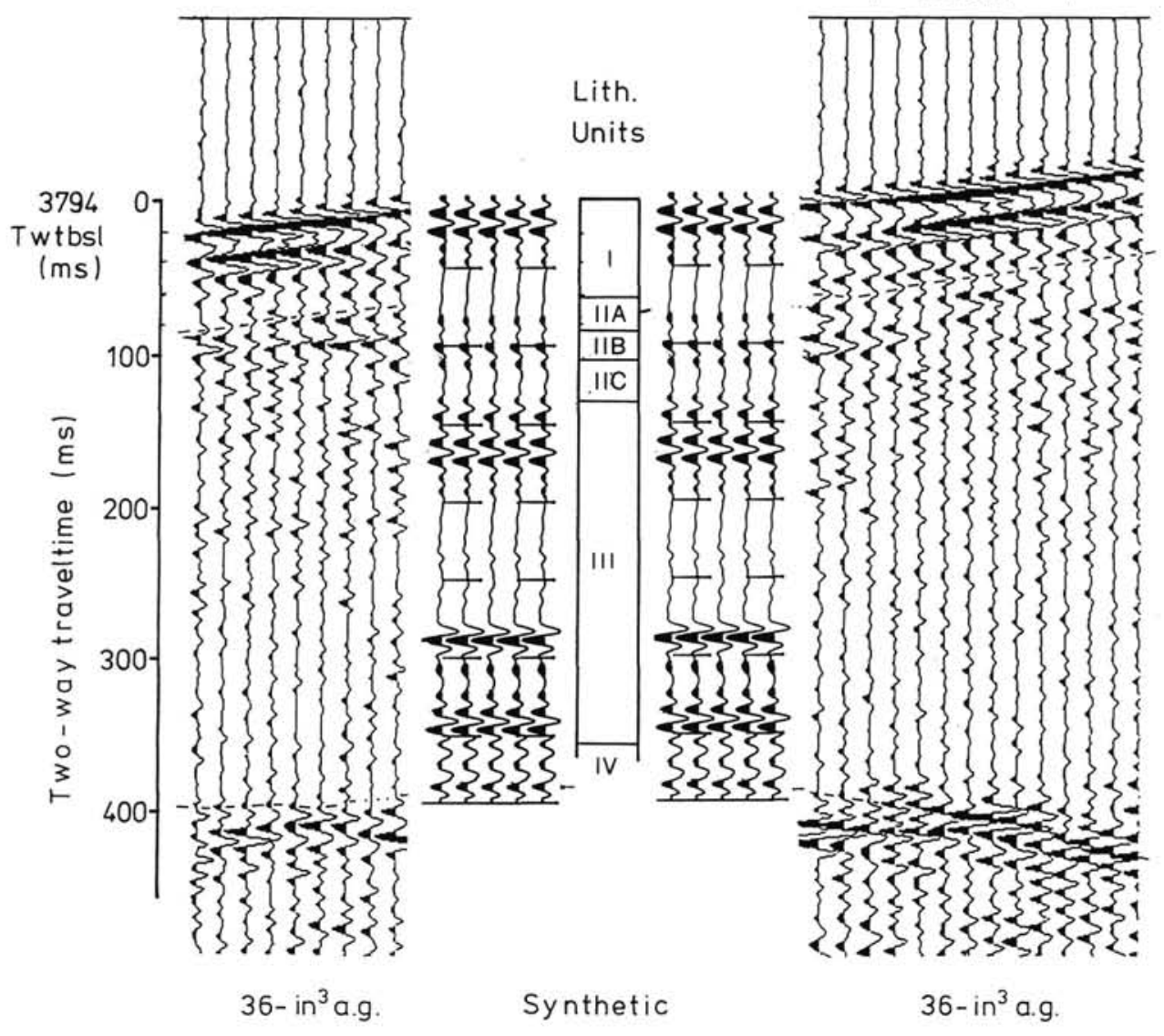

Figure 11. Comparison of the field record with the synthetic seismogram and lithologic units at Site 643 . a.g. = air gun. Data are filtered $(50-150 \mathrm{~Hz})$ and the amplitude is linearly amplified by a factor of four. 